\title{
PENGARUH PEMBERIAN KOMPRES HANGAT MEMAKAI PARUTAN JAHE MERAH TERHADAP PENURUNAN SKALA NYERI PADA WANITA LANSIA PENDERITA GOUT ARTHRITIS DI PANTI SOSIAL TRESNA WERDHA TERATAI PALEMBANG TAHUN 2018
}

\author{
Zakinah Arlina \\ Program Studi DIII Keperawatan STIKES Mitra Adiguna Palembang. \\ Komplek Kenten Permai Blok J No 9-12 Bukit Sangkal Palembang 30114 \\ Linasalam2004@gmail.com
}

\begin{abstract}
Abstrak
Penderita arthritis rheumatoid di seluruh dunia telah mencapai angka 355 juta jiwa, artinya 1 dari 6 orang di dunia ini menderita rheumatoid. Menurut data dari Panti Sosial Tresna Werdha Teratai Palembang, jumlah penderita penyakit sendi dan tulang tahun 2015 jumlah lansia penghuni panti sebanyak 62 orang, pada tahun 2016 sebanyak 70 orang, dan pada tahun 2017 sebanyak 70 orang, adapun jumlah lansia berjenis kelamin wanita sebanyak 45 orang. Penelitian ini bertujuan untuk mengetahui pengaruh pemberian kompres hangat memakai parutan jahe merah terhadap penurunan skala nyeri pada wanita lansia penderita gout arthritis di Panti Sosial Tresna Werdha Teratai Palembang tahun 2018. Penelitian ini merupakan penelitian kuantitatif dengan menggunakan metode survei analitik. Teknik pengambilan sampel pada penelitian ini menggunakan cara non random (non probability) sampling dengan metode total sampling yaitu pengambilan seluruh anggota populasi untuk dijadikan sampel yang berjumlah 45 orang. Hasil penelitian Nilai rata-rata sebelum diberikan kompres hangat adalah 6,76 dengan standar devisiasi 0,908. Nilai minimum sebelum diberikan kompres adalah 5 sedangkan nilai maksimum 9. Nilai rata-rata sesudah diberikan kompres hangat adalah 3,44 dengan standar devisiasi 1,439. Nilai minimum sebelum diberikan kompres adalah 1 sedangkan nilai maksimum 6. Ada pengaruh pemberian kompres hangat memakai parutan jahe merah terhadap penurunan skala nyeri pada wanita lansia penderita gout arthritis di Panti Sosial Tresna Werdha Teratai Palembang tahun 2018 ( $p$ value $=0,001)$.
\end{abstract}

$\begin{array}{ll}\text { Kata Kunci } & : \text { Nyeri, Athritis Gout, Kompres Jahe Merah } \\ \text { Daftar bacaan } & : 16(2002-2017)\end{array}$

Abstract

Rheumatoid arthritis sufferers worldwide have reached 355 million, meaning that 1 in 6 people in the world suffer from rheumatoid. According to data from the Tresna Werdha Lotus Lotus Orphanage in Palembang, the number of people with joint and bone diseases in 2015 the number of elderly residents of the orphanage was 62 people, in 2016 as many as 70 people, and in 2017 as many as 70 people, as for the number of elderly women as many as 45 people. This study aims to determine the effect of giving warm compresses using grated red ginger on the decrease in pain scale in elderly women with gout arthritis in Tresna Werdha Lotus Lotus Social Home in 2018. This research is a quantitative study using analytic survey methods. The sampling technique in this study uses a non random (non probability) sampling method with a total sampling method that is taking all members of the population to be a sample of 45 people. Results of the study The average value before being given a warm compress was 6.76 with a standard deviation of 0.908. The minimum value before giving a compress is 5 while the maximum value is 9 . The average value after giving a warm compress is 3.44 with a standard deviation of 1.439. The minimum value before giving a compress is 1 while the maximum value is 6 . There is an effect of giving warm compresses using grated red ginger on the decrease in pain scale in elderly women suffering from gout arthritis at Tresna Werdha Lotus Lotus Social Home in Palembang in 2018 ( $p$ value $=0.001$ ).

Keywords Reading list

: Pain, Gout Athritis, Red Ginger Compress

: $16(2002$ - 2017)

Jurnal Kesehatan dan Pembangunan, Vol. 9, No.18, Juli 2019 


\section{PENDAHULUAN}

Artritis Reumatoid (AR) salah satu dari beberapa penyakit rematik adalah suatu penyakit otoimun sistemik yang menyebabkan peradangan pada sendi. Penyakit ini ditandai oleh peradangan sinovium yang menetap, suatu sinovitis proliferatifa kronik non spesifik. Dengan berjalannya waktu, dapat terjadi erosi tulang, destruksi (kehancuran) rawan sendi dan kerusakan total sendi. Akhirnya, kondisi ini dapat pula mengenai berbagai organ tubuh (Rosyidi, 2012).

Penderita arthritis rheumatoid di seluruh dunia telah mencapai angka 355 juta jiwa, artinya 1 dari 6 orang di dunia ini menderita rheumatoid. Diperkirakan angka ini terus meningkat hingga tahun 2025 dengan indikasi lebih dari 25\% akan mengalami kelumpuhan. Organisasi kesehatan dunia (WHO) melaporkan bahwa $20 \%$, penduduk dunia terserang penyakit arthritis rheumatoid. Dimana 5$10 \%$ adalah mereka yang berusia 5-20 tahun dan $20 \%$ mereka yang berusia 55 tahun (Wiyono, 2015).

Tindakan non farmakologis untuk penderita gout arthritis diantaranya adalah kompres, baik itu kompres hangat dan kompres dingin.Kompres merupakan tindakan mandiri perawat dalam upaya menurunkan suhu tubuh (Potter, 2005). Jahe merah biasa digunakan sebagai campuran bahan obat. Hal ini disebabkan adanya efek farmakologis jahe merah dapat memperkuat khasiat bahan lain yang dicampurkan sebagai ramuan herbal. Bagian tanaman jahe merah yang diguanakan untuk pengobatan asam urat adalah rimpanya (Herliana dalam Izza, 2014)

Kompres jahe dapat menurunkan nyeri sendi, karena jahe dapat meningkatkan kemampuan kontrol terhadap nyeri. Jahe memiliki rasa pedas dan bersifat hangat. Beberapa bahan dalam jahe diantaranya gingerol, limonene, $\alpha$-linolenic acid, aspartic, $\beta$ sitosterol, tepung kanji, caprylic acid, capsaicin, chlorogenic acid, dan farnesol. Efek farmakologis yang dimiliki jahe diantaranya, merangsang ereksi, penghambat keluarnya enzim 5lipooksigenase dan siklooksigenase serta meningkatkan aktivitas kelenjar endokrin (Heriana dalam Izza, 2014). Jahe sering sekali digunakan sebagai obat nyeri sendi karena kandungan gingerol dan rasa hangat yang ditimbulkannya membuat pembuluh darah terbuka dan memperlancar sirkulasi darah. Alhasil, suplai makanan dan oksigen menjadi lebih baik sehingga nyeri sendi akan berkurang (Puspaningtyas \& Utami dalam Izza, 2014).

Pada tahun 2014 di Palembang, jumlah penduduk lansia yang menderita penyakit pada sistem otot dan jaringan termasuk rematik berjumlah 41.605 orang. Jumlah tersebut meningkat menjadi 44.200 orang penderita pada tahun 2015, dan angka tersebut meningkat lagi menjadi 45.070 pada tahun 2016 (Dinkes Palembang, 2016).

Menurut data dari Panti Sosial Tresna Werdha Teratai Palembang, jumlah penderita penyakit sendi dan tulang tahun 2015 jumlah lansia penghuni panti sebanyak 62 orang, pada tahun 2016 sebanyak 70 orang, dan pada tahun 2017 sebanyak 70 orang, adapun jumlah lansia berjenis kelamin wanita sebanyak 45 orang (Profil Panti Sosial Tresna Werdha Teratai Palembang, 2017)

Berdasarkan uraian di atas, penulis tertarik untuk melakukan penelitian mengenai "Pengaruh pemberian kompres hangat memakai parutan jahe merah terhadap wanita lansia penurunan skala nyeri pada penderita gout arthritis di Panti Sosial Tresna Werdha Teratai Palembang tahun 2018".

\section{METODOLOGI PENELITIAN Ruang Lingkup Penelitian}

Penelitian ini menggunakan jenis penelitian Pre Experimental Design dengan rancangan penelitian One-group pra-post test design yang dilakukan pada 
satu kelompok tanpa kelompok control. Kelompok subjek diobservasi sebelum dilakukan intervensi (pre-test) kemudian diobservasi lagi setelah intervensi (posttest). Intervensi yang diberikan berupa therapy kompres hangat jahe merah yang akan diberikan lansia dan akan diberikan perlakukan dan perbandingan sebelum dan sesudah dilakukan therapy kompres hangat menggunakan parutan jahe merah.

\section{Waktu Penelitian dan Tempat Penelitian}

Penelitian dilaksanakan di Panti Sosial Tresna Werdha Teratai Palembang. Pelaksanaan penelitian ini dilakukan pada tanggal 17 April sampai 28 April 2018

\section{Populasi dan Sampel}

Populasi

Populasi penelitian adalah keseluruhan objek penelitian atau objek yang diteliti (Notoatmodjo, 2012). Populasi pada penelitian ini adalah pasien lansia yang mengalami arthritis gout di Panti Sosial Tresna Werdha Teratai Palembang tahun 2018.

\section{Sampel}

Sampel penelitian adalah sebagian yang diambil dari keseluruhan objek yang diteliti dan dianggap mewakili seluruh populasi (Notoatmodjo, 2012). Peneliti menentukan sampel dalam penelitian ini menggunakan metode total sampling yaitu pengambilan semua anggota populasi yaitu wanita lansia untuk dijadikan sampel. Jumlah sampel pada penelitian ini sebanyak 45 orang wanita lansia.

\section{Pengumpulan Data}

Pengumpulan data dalam penelitian ini dilakukan peneliti setelah mendapatkan izin secara tertulis atau lisan dari pihak tim skripsi STIKES Mitra Adiguna Palembang dan Kepala Unit Diklat dan Kepala Pimpinan Panti Sosial Tresna Werdha Teratai Palembang. Kemudian peneliti melakukan studi pendahuluan untuk mengetahui keadaan di lapangan dengan melakukan studi dokumentasi dan mencatat data-data jumlah lansia yang mengalami athrititis gout Palembang yang didapat dari ruang rekam medik dalam rangka penyusunan proposal untuk menggambarkan penelitian ini. Sebelum penelitian, peneliti terlebih dahulu menentukan calon responden sesuai dengan kriteria yang telah ditentukan. Peneliti menyiapkan lembaran observasi dan lembar informed consent.

\section{HASIL PENELITIAN \\ Analisa Univariat}

Analisa ini digunakan untuk memperoleh gambaran distribusi frekuensi dan persentase dari semua variabel yang diteliti yaitu untuk mengetahui pengaruh pemberian kompres hangat memakai parutan jahe merah terhadap penurunan skala nyeri pada wanita lansia penderita gout arthritis di Panti Sosial Tresna Werdha Teratai Palembang tahun 2017. Maka didapatkannya hasil sebagai berikut:

Nyeri pada Penderita Lansia Sebelum Diberikan Kompres Hangat

Skala nyeri pada wanita lansia penderita gout arthritis sebelum diberikan kompres hangat memakai parutan jahe dapat dilihat pada tabel dibawah ini:

Tabel 4.1

Distribusi Frekuensi Responden

Berdasarkan Skala Nyeri Sebelum

Diberikan Kompres Hangat di Panti Sosial Tresna Werdha Teratai Palembang Tahun 2018

\begin{tabular}{cccccc}
\hline No & Variabel & N & Mean & SD & Min-Max \\
\hline 1 & Pre test & 45 & 6,76 & 0,908 & $5-9$
\end{tabular}

Dari tabel 4.1 didapatkan bahwa nilai rata-rata sebelum diberikan kompres hangat adalah 6,76 dengan standar devisiasi 0,908. Nilai minimum sebelum diberikan kompres adalah 5 sedangkan nilai maksimum 9 . 
Nyeri pada Penderita Lansia Sesudah Diberikan Kompres Hangat

Skala nyeri pada wanita lansia penderita gout arthritis sesudah diberikan kompres hangat memakai parutan jahe dapat dilihat pada tabel dibawah ini:

Tabel 4.2

Distribusi Frekuensi Responden Berdasarkan Skala Nyeri Sesudah Diberikan Kompres Hangat di Panti Sosial Tresna Werdha Teratai Palembang Tahun 2018

\begin{tabular}{cccc}
\hline No & Variabel & Nilai & Keterangan \\
\hline 1 & Pre test & 0,001 & Tidak normal \\
& & & \\
\hline 2 & Post test & 0,002 & Tidak normal \\
& & & \\
\hline
\end{tabular}

Dari tabel 4.2 didapatkan bahwa nilai rata-rata sesudah diberikan kompres hangat adalah 3,44 dengan standar devisiasi 1,439. Nilai minimum sebelum diberikan kompres adalah 1 sedangkan nilai maksimum 6 .

\section{Analisa Bivariat}

Hasil analisa bivariat ini digunakan untuk melihat pengaruh pemberian kompres hangat memakai parutan jahe merah terhadap penurunan skala nyeri pada wanita lansia penderita gout arthritis di Panti Sosial Tresna Werdha Teratai Palembang tahun 2017. Pada setiap variabel analisa statistik secara bivariat pada penelitian ini menggunakan uji $t$ Dependen dengan $\alpha=5 \%(0,05)$ dengan membandingkan nilai $\mathrm{p}$ dengan $\alpha$.

\section{Uji Normalitas Data}

Sebelum melakukan uji t dependen terlebih dahulu dilakukan uji normalitas data dengan menggunakan Shapiro-wilk. Hasil uji normalitas dapat dilihat pada tabel dibawah ini:
Tabel 4.3

Hasil Uji Normalitas Data Pengaruh Pemberian Kompres Hangat memakai Parutan Jahe Merah Terhadap Penurunan Skala Nyeri pada Pasien Wanita Lansia Penderita Gout Athritis di Panti Sosial Tresna

Werdha Teratai Palembang tahun 2018

\begin{tabular}{cccccc}
\hline No & Variabel & N & Mean & SD & $\begin{array}{l}\text { Min- } \\
\text { Max }\end{array}$ \\
\hline 1 & Post test & 45 & 3,44 & 1,439 & $1-6$ \\
\hline
\end{tabular}

Berdasarkan tabel di atas setelah dilakukan uji normalitas diketahui bahwa nilai variabel pre test $0,001<0,05$ dan nilai post test $0,002<0,05$ sehingga data berdistribusi tidak normal. Jadi untuk analisa bivariat karena data berdistribusi tidak normal maka dilakukan uji wilcoxon.

Pengaruh pemberian kompres hangat memakai parutan jahe merah terhadap penurunan skala nyeri pada wanita lansia penderita gout arthritis

Tabel 4.4

Pengaruh Pemberian Kompres Hangat Memakai Parutan Jahe Merah Terhadap Penurunan Skala Nyeri Pada Wanita Lansia Penderita Gout Arthritis Di Panti Sosial Tresna Werdha Teratai Palembang Tahun 2018

\begin{tabular}{clccccc}
\hline No & Variabel & n & Mean & SD & $\begin{array}{c}\text { Min- } \\
\text { Max }\end{array}$ & $\begin{array}{c}\boldsymbol{p} \\
\text { value }\end{array}$ \\
\hline 1 & Pre test & & & & & \\
2 & Post test & & 6,76 & 0,908 & 2,882 & \\
& & 45 & 3,44 & 1,439 & 3,740 & 0,001 \\
& & & & & &
\end{tabular}

Berdasarkan tabel diatas diketahui bahwa nilai rata-rata sebelum diberikan kompres hangat adalah 6,76 dengan standar devisiasi 0,908 dan nilai rata-rata 
sesudah diberikan kompres hangat adalah 3,44 dengan standar devisiasi 1,439 , nilai minimum yaitu 2,882 dan nilai maksimum 3,740. Hasil uji statistik diperoleh nilai $p$ value $(0,001)$ yang berarti bahwa ada pengaruh pemberian kompres hangat memakai parutan jahe merah terhadap penurunan skala nyeri pada wanita lansia penderita gout arthritis di Panti Sosial Tresna Werdha Teratai Palembang tahun 2018.

\section{PEMBAHASAN}

\section{Keterbatasan Penelitian}

Dalam pelaksanaan penelitian ini, peneliti menyadari tidak lepas dari kekurangan dan keterbatasan yang ada meskipun telah diupayakan sebaik mungkin untuk mengatasinya. Adapun keterbatasan dalam penelitian ini, yaitu:

a. Peneliti menggunakan metode pre experimental design dengan menggunakan pendekatan pre dan post only design, dimana memerlukan waktu penelitian yang cukup lama untuk hasil yang baik, tetapi karena keterbatasan waktu penelitian yang singkat maka peneliti berusaha untuk melakukan penelitian ini dengan maksimal dan hasil yang baik.

b. Peneliti kesulitan dalam meminta ketersediaan responden dikarenakan responden sudah lansia dan mengalami sakit sehingga sulit untuk dilakukan meminta keterangan.

\section{Analisis Bivariat}

\section{Pengaruh Pemberian Kompres Hangat Memakai Parutan Jahe Merah Terhadap Penurunan Skala Nyeri Pada Wanita Lansia Penderita Gout Arthritis}

Berdasarkan hasil penelitian diketahui bahwa nilai rata-rata sebelum diberikan kompres hangat adalah 6,76 dengan standar devisiasi 0,908 dan nilai rata-rata sesudah diberikan kompres hangat adalah 3,44 dengan standar devisiasi 1,439, nilai minimum yaitu 2,882dan nilai maksimum 3,740. Hasil uji statistik diperoleh nilai $p$ value $(0,001)$ yang berarti bahwa ada pengaruh pemberian kompres hangat memakai parutan jahe merah terhadap penurunan skala nyeri pada wanita lansia penderita gout arthritis di Panti Sosial Tresna Werdha Teratai Palembang tahun 2018.

Hasil penelitian ini sesuai dengan pendapat Puspaningtyas \& Utami dalam Izza (2014), kompres jahe dapat menurunkan nyeri sendi, karena jahe dapat meningkatkan kemampuan kontrol terhadap nyeri. Jahe memiliki rasa pedas dan bersifat hangat. Beberapa bahan dalam jahe diantaranya gingerol, limonene, $\alpha$-linolenic acid, aspartic, $\beta$ sitosterol, tepung kanji, caprylic acid, capsaicin, chlorogenic acid, dan farnesol. Efek farmakologis yang dimiliki jahe diantaranya, merangsang ereksi, penghambat keluarnya enzim 5lipooksigenase dan siklooksigenase serta meningkatkan aktivitas kelenjar endokrin (Heriana dalam Izza, 2014). Jahe sering sekali digunakan sebagai obat nyeri sendi karena kandungan gingerol dan rasa hangat yang ditimbulkannya membuat pembuluh darah terbuka dan memperlancar sirkulasi darah. Alhasil, suplai makanan dan oksigen menjadi lebih baik sehingga nyeri sendi akan berkurang.

Penelitian ini juga sesuai dengan teori Mahmud (2007), kompres air hangat adalah memberikan rasa hangat untuk memenuhi kebutuhan rasa nyaman, mengurangi atau membebaskan nyeri, mengurangi atau mencegah spasme otot dan memberikan rasa hangat pada daerah tertentu. Beberapa literatur mendukung kompres air hangat dengan suhu $106-$ $110 \mathrm{~F}\left(41-43^{\circ} \mathrm{C}\right)$. Batas suhu tersebut dianggap fisiologis untuk kompres dan telah diuji melalui beberapa penelitian dengan risiko terjadinya heatstroke yang minimal. Pemberian kompres air hangat dilakukan selama 20 - 30 menit karena menyebabkan vasodilatasi maksimum, dan kompres lebih dari suhu tersebut akan 
mengakibatkan kongesti jaringan, dan pembuluh darah kemudian berkonstriksi dengan alasan yang tidak diketahui. Apabila kompres panas terus dilanjutkan, klien beresiko mengalami luka bakar, karena pembuluh darah yang berkonstriksi tidak mampu membuang panas secara adekuat melalui sirkulasi darah. Kompres air hangat di kulit, khususnya pada perut menimbulkan sensasi suhu pada nerve ending (ujung syaraf) pada permukaan kulit.

Hasil penelitian ini sejalan dengan hasil penelitian Yuniarti (2015) tentang pengaruh pemberian kompres hangat jahe terhadap skala nyeri sendi pada pasien artritis rheumatoid Desa Bleberan Kecamatan Jatirejo Kabupaten Mojokerto. Hasil uji Wilcoxon menunjukkan data bahwa $\rho=0,001$ dan $\alpha=0,05$ sehingga $\rho$ $<\alpha$ maka $\mathrm{H}_{0}$ ditolak dan $\mathrm{H}_{1}$ diterimasehingga ada pengaruh pemberian kompres hangat jaheterhadap skala nyeri sendi pada pasien artritis rheumatoid Desa Bleberan Kecamatan Jatirejo Kabupaten Mojokerto.

Dari hasil penelitian tersebut menyimpulkan bahwa skala nyeri pada penderita arthritis gout dapat diturunkan dengan cara memberikan kompres hangat memakai parutan jahe merah karena dengan kompres hangat tersebut dapat memberikan rasa hangat untuk memenuhi kebutuhan rasa nyaman, mengurangi atau membebaskan nyeri, mengurangi atau mencegah spasme otot dan memberikan rasa hangat pada penderita arthritis hingga mengurangi rasa nyeri yang dialami.

\section{SIMPULAN DAN SARAN}

\section{Simpulan}

Dari hasil penelitian yang telah dilakukan dapat disimpulkan bahwa :

1. Nilai rata-rata sebelum diberikan kompres hangat adalah 6,76 dengan standar devisiasi 0,908. Nilai minimum sebelum diberikan kompres adalah 5 sedangkan nilai maksimum 9.
2. Nilai rata-rata sesudah diberikan kompres hangat adalah 3,44 dengan standar devisiasi 1,439 . Nilai minimum sebelum diberikan kompres adalah 1 sedangkan nilai maksimum 6 .

3. Ada pengaruh pemberian kompres hangat memakai parutan jahe merah terhadap penurunan skala nyeri pada wanita lansia penderita gout arthritis di Panti Sosial Tresna Werdha Teratai Palembang tahun 2017 ( $p$ value = 0,001)

\section{Saran}

1. Bagi Panti Sosial Tresna Werdha Teratai Palembang

Diharapkan pada pihak panti agar penelitian ini bisa menjadi bahan kebijakan atau pertimbangan untuk dapat memberikan terapi kompres hangat menggunakan jahe merah untuk menurunkan skala nyeri pada penderita arthritis gout.

2. Bagi STIKES Mitra Adiguna Palembang

Diharapkan dasil penelitian ini dapat menjadi sumber bacaan untuk menambah ilmu pengetahuan, informasi bagi peserta didik dimasa yang akan datang dan dapat digunakan untuk melengkapi referensi kepustakaan STIKES Mitra Adiguna Palembang.

3. Bagi Peneliti Selanjutnya

Diharapkan hasil penelitian ini diharapkan dimasa yang akan datang penelitian mengenai arthritis gout dapat terus dikembangkan seperti mengadakan penelitian eksperimen. Tentang kandungan dari jahe merah yang dapat menurunkan skala nyeri karena didalam jahe merah memiliki rasa pedas dan bersifat hangat sehingga dapat membuat pembuluh darah terbuka dan memperlancar sirkulasi darah.

\section{DAFTAR PUSTAKA}

Jurnal Kesehatan dan Pembangunan, Vol. 9, No.18, Juli 2019 
Aqila, Smart. 2010. Waspadai Gangguan Rematik. Yogyakarta : Kanisius

Aziz, Sriana. 2009. Hidup Sehat Menyeluruh dan Alami. Jakarta: Tim Indocamp

Brunner \& Suddarth. 2002. Buku Ajar Keperawatan Medikal-Bedah. Terjemahan Suzanne C. Smeltzer. Edisi 8. Vol 8. Penerbit Buku Kedokteran EGC: Jakarta.

Dana Ali. 2015. Angka Kejadian Rematik di Dunia dan Indonesia. (Online) at http://angka-rematikdidunia.blogspot.

Dinas Kesehatan Palembang, 2016. Profil Kesehatan Kota Palembang. Palembang: Dinkes

Holmann. DB. 2012. Pedoman Praktek Keperawatan. Alih Bahasa: Setiawan. Jakarta: EGC.

Izza, S. 2014. Perbedaan Efektivitas Pemberian Kompres Air Hangat dan Pemberian Kompres Jahe Terhadap Penurunan Nyeri Sendi pada Lansia di Unit Rehabilitasi Sosial Wening Wardoyo Ungaran. Jurnal STIKES Ngudi Waluyo Ungaran.

Junaidi, Iskandari. 2013. Rematik dan Asam Urat. Edisi Revisi. Jakarta: PT. Bhuana Ilmu Populer.

Notoatmodjo, Soekidjo. 2012. Metodologi Penelitian Kesehatan. Jakarta : PT Rineka Cipta

Profil Panti Sosial Tresna Werdha Teratai Palembang Tahun 2017.

Puwoastuti. E. 2009. Epidemiologi Penyakit Tidak Menular. Cetakan 2. Jakarta: Rineka Cipta
Randa, Gusti. 2013. Rematik, Asam Urat, Hiperurisemia, Atritis Gout. Jakarta: Pustaka Obor Populer Rosyidi, Kholid. 2012. Muskuloskletal. Jakarta: CV. Trans Info Media

Wijaya, Handono. 2012. Ilmu Penyakit Dalam. Jakarta: Balai Penerbit FKUI

Wiyono, A.K. 2015. Angka Kejadian Rematik di Dunia. (Online) at http://angka-kejadian-rematikdidunia.html

Zuljasari, Siti. 2014. Rematik dan Upaya Pencegahannya. (Online) at http://penyakit-rematik-dan-upayapencegahannya//html diakses 